Kredo 3 (2020)
KREDO: Jurnal Ilmiah Bahasa dan Sastra
Terakreditasi Sinta 4 berdasarkan Keputusan Direktorat
Jenderal Penguatan Riset dan Pengembangan,
Kementerian Riset, Teknologi dan Pendidikan Tinggi
Republik Indonesia
Nomor: 23/E/KPT/2019. 08 Agustus 2019
https://jurnal.umk.ac.id/index.php/kredo/index

\title{
Diskriminasi Terhadap Etnik Tionghoa dalam Novel Entrok Karya Okky Madasari
}

\section{Isqi Agustin Cahyaningtiyas ${ }^{1}$, Candra Rahma Wijayaputra ${ }^{2}$ Cahyanintiyas25@gmail.com ${ }^{1}$}

Prodi Pendidikan Bahasa dan Sastra Indonesia, Fakultas Keguruan dan Ilmu Pendidikan Universitas Muhammadiyah Malang

\section{Info Artikel \\ Sejarah \\ Artikel \\ Diterima 10 \\ Januari 2020 \\ Disetujui 24 Maret 2020 \\ Dipublikasikan 29 \\ April 2020}

Keywords

hegemoni

gramsci,

discrimination,

tionghoa

Kata Kunci

hegemoni

gramsci,

diskriminasi,

tionghoa

\section{Abstract}

: The focus of this research is first to describe the domination of the State to the Chinese by force, secondly to describe the purpose of the domination by the State of the ethnic Chinese. This research uses Antonio Gramsci's perspective hegemony theory. The method of data collection in this study uses literature study, the researcher collects and reads a number of libraries that are related to the theory and the objects used, namely Entrok novels and the study of hegemony theory with a sociological approach to literature. In general, discrimination is a difference in attitude or treatment of fellow citizens based on differences in ethnicity, class, economy, skin color and religion. The results of this study indicate (1) the dominance of the State over the ethnic Chinese by means of physical violence, mental violence and mental violence, (2) the purpose of the Domination Given by the State Against the Chinese Ethnic due to the injustice of the indigenous and ethnic Chinese communities, that is solely eyes because of the ethnic Chinese conditions that are more fortunate and prosperous than those of the indigenous people. That caused the State to make a decision by implementing an assimilationation : $\quad$ policy that made it difficult for all Chinese ethnic activities.

\section{Abstrak}

Fokus penelitian ini yaitu pertama mendeskripsikan dominasi Negara kepada Tionghoa dengan kekerasan, kedua mendekskripsikan tujuan dominasi yang dilakukan Negara terhadap Tionghoa. Penelitian ini menggunanakan teori hegemoni perspektif Antonio Gramsci. Metode pengumpulan data penelitian ini menggunakan studi pustaka, yaitu peneliti mengumpulkan dan membaca beberapa : pustaka yang ada kaitannya dengan teori maupun objek yang dipakai, yaitu novel Entrok dan kajian teori hegemoni dengan pendekatan sosiologi sastra. Secara umum diskriminasi merupakan pembedaan sikap atau perlakuan terhadap sesama warga negara berdasarkan perbedaan suku, golongan, ekonomi, warna kulit dan agama. Hasil penelitian ini menunjukkan (1) dominasi yang dilakukan negara terhadap etnik Tionghoa dengan cara kekerasan fisik, kekerasan batin dan kekerasan mental, (2) tujuan dominasi yang diberikan negara terhadap etnik tionghoa karena adanya ketidak adilan masyarakat pribumi dan etik Tionghoa, hal itu semata-mata karena keadaan etnis tionghoa yang lebih beruntung serta hidup makmur dibandikan dengan masyarakat pribumi. Hal itu menyebabkan Negara mengambil keputusan dengan memberlakukan kebijakan asimilasi yang mempersulit segala kegiatan etnik Tionghoa. 


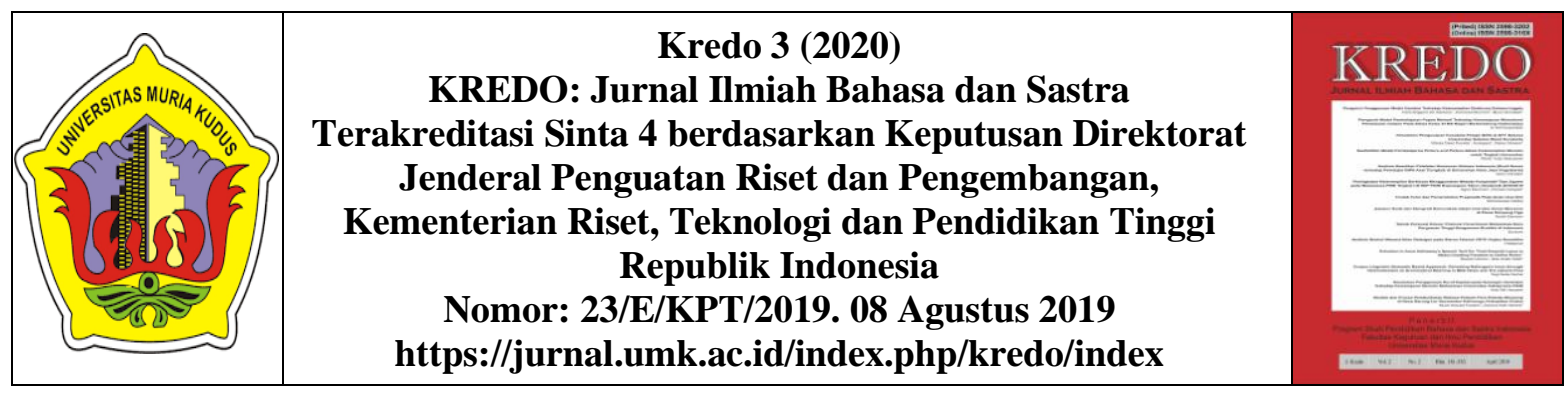

\section{PENDAHULUAN}

Indonesia merupakan negara dengan masyarakat yang memiliki latar belakang yang berbeda. Baik dari suku dan budaya. Dibalik keindahan perbedaan itu tentunya terdapat permasalahan yang klasik bagi negara indonesia. Hal ini dapat terjadi karena sering terjadinya pertentangan antar suku. Contohnya seperti pertentangan masyarakat pribumi dengan etnis Tionghoa.

Awal pemerintahan Orde Baru, menunjukkan langgam libertarian yang nyata adalah langgam perpindahan dengan mencari format baru bagi konfigurasi politik (Nurcahyo, 2016). Masa Orde Baru memberlakukan sistem kebijakan asimilasi. Menurut Park dan Burges (Romli, 2015) asimilasi adalah suatu proses interpretasi dan fusi. Melalui proses ini orang-orang dan kelompok-kelompok memperoleh memori-memori, sentimensentimen, dan sikap-sikap orang-orang atau kelompokkelompok lainnya, dengan berbagai pengalaman dan sejarah, tergabung dengan mereka dalam suatu kehidupan budaya yang sama. Proses ini mencampurkan dua budaya atau lebih sehingga membentuk kebudayaan baru. Golongan yang melakukan asimilasi ini adalah golongan mayoritas dan golongan minoritas. Tionghoa merupakan etnis yang banyak melakukan perpindahan kedaerah lain, termasuk diantarannya daerah barat dan Asia, baik dengan hubungan perdagangan maupun ekspedisi. Tionghoa merupakan etnis yang mampu mempertahankan jati dirinya ditempat, tanpa sedikitpun menghilangkan kultur dan budayanya (Khaliesh, 2014).
Pada kenyatannya keberadaan masyarakat etnik Tionghoa belum bisa diterima dengan baik oleh masyarakat pribumi Indonesia. Banyak pandangan negatif yang muncul dari pemikiran pribumi. Masyarakat keturunan Cina atau etnik Tinghoa dicurigai masih menjalin hubungan yang kuat dengan tanah asli leluhurnya dan ditakutkan rasa nasionalisme terhadap negara Indonesia diragukan serta dikhawatirkan melakukan penjajahan yang sma, yang telah dilakukan oleh Belanda.

Banyak peristiwa pahit yang dialami oleh etnis Tionghoa di Indonesia, salah satunya seruan kepada masyarakat pribumi untuk mengusir orang Tionghoa yang memiliki status kewarganegaraan Cina. Tututan tersebut hasil reaksi dari perdebatan antara pemerintah Indonesia dan pemerintah Cina. Perdebatan itu tentang tuntutan pemerintah RRC terhadap pemerintah Republik Indonesia supaya menyediakan kapal bagi Tionghoa yang ingin kembali ke negaranya. Dari hal tersebut pemerintah republik Indonesia dianggap gagal dalam menjaga kepentingan etnis Tionghoa asing di Indonesia.

Kebijakan asimilasi pada masa Orde Baru terhadap etnis Tionghoa lebih ditekankan dan cenderung dipaksakan. Tujuannya supaya menghilangkan identitas ketionghoa-an dan didorong menjadi lebih ke- "Indonesia". Dalam masa kebijakan asimilasi dijalankan, presiden Soeharto pribadi yang menyatakan bahwa secara jelas dan secepatnya warga negara Indonesia yang berdarah Cina, harus segera berintegrasi 


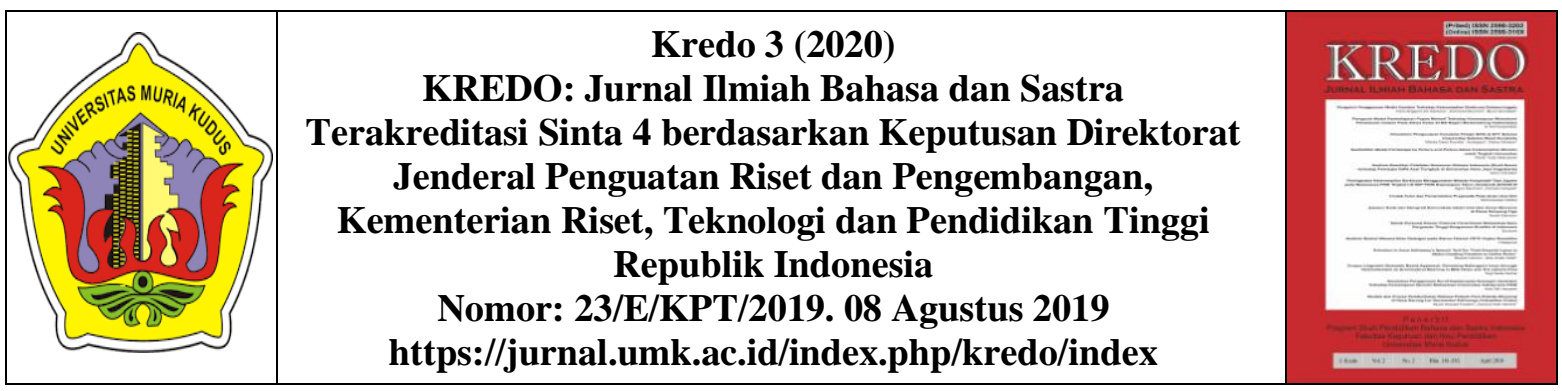

dan berasimilasi bersama masyarakat Indonesia asli (Suryadinata, 2014). Dalam masa ini ditetapkan peraturan negara yang merajuk deskriminasi kepada etnik Tionghoa diantarannya (1) pelarangan menggunakan Bahasa Mandari dan festifal kebudayaan Tionghoa, pemerintah menutup sekolah bahasa Mandarin dan menjadikan anakanak keturunan Tionghoa wajib mempelajari bahasa Indonesia desakan mengganti nama yang berunsur Indonesia sehingga muncul nama Gana Dipanegara, (3) pembatasan untuk etnik Tionghoa memasuki dunia politik, sipil, dan militer, (4) etnik Tionghoa masih mendapatkan perlakuan tetap (deskriminasi) yaitu dikenai prasangka rasial serta cenderung menjadi sasaran pandangan anti Cina (Adam, 2019: 3).

Secara umum diskriminasi merupakan pembedaan sikap atau perlakuan terhadap sesama warga negara berdasarkan perbedaan suku, golongan, ekonomi, warna kulit dan agama. Adannya diskriminasi terhadap etnis Tioghoa dilandasi dengan beberapa alasan. Pertama etnis Tionghoa tidak memiliki tempat yang tetap di Indonesia untuk menjadi wilayah mereka. Kedua sebelum Perang Dunia II bangsa Indonesia tidak menganggap etnis Tionghoa sabagai tokoh Nasionalis.

Terbukti dengan beberapa pahlawan di Indonesia tidak menyebutkan satupun dari etnis Tinghoa. Pada kenyatannya ada banyak pahlawan dari etnis Tionghoa yang ikut andil dalam memperjuangkan kemerdekaan Indonesia, contohnya seperti Lie Yun Fong yang jasanya selalu menulis surat kabar tentang perlawanan rakyat Indonesia yang menolak bahwa bangsa ini masih dipimpin oleh Belanda. John Lie, yang dijuluki sebagai hantu selat 72 | Jurnal Kredo Vol. 3 No. 2 April 2020 malaka karena keberhasilannya dalam menyelundupkan senjata, guna diberikan kepada pejuang tanah air. Oei Hok San, sebagai mantan tentara pelajar yang berada di Kediri dengan perjuannya meninggalkan pesan untuk dibuatkan monumen yang berisi nama temantemannya yang turut berjuang untuk Indonesia, dia tidak ingin orang-orang yang memperjuangkan Indonesia dilupakan begitu saja. Oei Tjong Hauw, sebagai salah satu anggota BPUPKI. Letkol Ong Tjong Bing, perannya merawat korban pertempuran 10 November yang dibawanya ke Malang. profesi dia sebagai dokter gigi yang menjadi relawan bagi korban yang membutuhkan perawatan.

Terbukti dengan beberapa pahlawan di Indonesia tidak menyebutkan satupun etnis Tinghoa. Menurut Suryadinata (Fittrya, 2013) ketiga etnis Tionghoa memiliki leluhur sendiri dan pemerintahan Cina menganggap orangorang Cina (etnis Tionghoa) sebagai warganegarannya. Hal itu menyebabkan masyarakat asli pribumi Indonesia meragukan rasa cinta etnis Tionghoa terhadap Negara Republik Indonesia.

Permasalahan yang terjadi pada etnis Tionghoa di Indonesia terjadi secara kompleks, bukan hanya tentang identitas kebangsaanya melainkan juga masalah politik, ekonomi dan kebudayaan yang mengalami perubahan. Hal ini terbukti ada beberapa kebijakan resmi yang dikeluarkan pemerintah pada mas Orde Baru yang menyebabkan nama baik etnis Tionghoa dinilai negatif. Menurut Suryadinata (Fittrya, 2013) kebijakan tersebut antara lain: (1) Intruksi presiden No. 14/1976 yang berisi larangan kegiatan keagamaan, kepercayaan dan adat Tionhoa di Indonesia. (2) Surat Edaran No. 


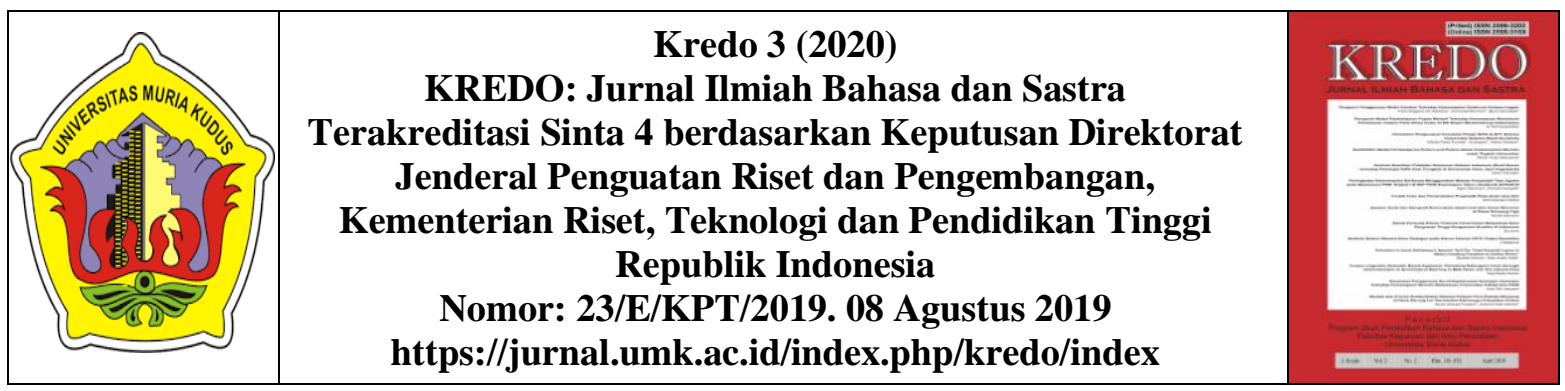

06/Preskab/6/1967 yang isinya menyatakan masyarakat Tionghoa harus mengubah namannya menjadi nama yang berbau Indonesia. (3) SK Mentri Perdagangan dan Koperasi No. 286/1978 tentang pelangan Impor, penjualan dan Penggunaan bahasa Cina. (4) Surat edaran SE.02/SE/Ditjen/PPG/K/1978, yang melarang penerbitan dan percetakan tulisan/iklan beraksara dan berbahasa Cina di depan umum. (5) Peraturan Menteri Perumahan No. 455.2$360 / 1988$, yang melarang penggunaan lahan untuk mendirikan, memperluas atau memperbarui Kelenteng. (6) Keputusan Presiden No. 56/1996 bertanggal 9 Juli 1996. Isinya, semua peraturan yang mensyaratkan SBKRI dihapus. Masa demokrasi terpemimpin pemerintah Indonesia juga mengeluarkan peraturan yang dianggap mendeskriminatif etnik Tionghoa dalam bidang ekonomi yaitu, PP No.10/1959 yang berisi tentang larangan orang-orang Tionghoa yang berada di pedesaan menciptakan adanya insiden. Dalam peraturan ini, pemerintah membatasi secara tegas peran dan hak ekonomi etnis Tionghoa (Nurcahyo, 2016). Atas peraturan itu mereka hanya diperbolehkan berdagang sampai wilayah kabupaten saja, tidak boleh pada daerah kecamatan atau sampai pada wilayah desa-desa. Hal ini bertujuan untuk para pedagang dan petani di desa dapat berkembang tanpa adanya orang asing yang membeli hasil pertanian mereka.

Permasalahan ekonomi yang rawan di Indonesia menjadi penyebab timbulnya pertentangan warga asli bumi dengan etnik Tionghoa. Etnik Tionghoa menjadi objek riri hati dan cacian serta makian karena mereka terampil dalam mengolah bidang ekonomi. Menurut Suryadinata (Dawis, 2013) diyakini 70\% perekonomian di Negeri ini dan merupakan $3 \%$ dari 240 juta penduduk yang berdomisilir di Indonesia. Dalam tata pemerintahan Orde Baru membatasi ruang gerak etnik Tionghoa. Kebijakan asimilasi pada masa Orde Baru menjadi pandangan negatif yang awet terhadap etnik Tionghoa yang jaman dulu disebut "Cina" punya label non pribumi. Peluang etnis Tionghoa untuk berwirausaha dibebaskan dalam kebijakan ekonomi Orde Baru. Hal tersebut menimbulkan kesenjangan sosial yang dirasakan oleh pribumi karena ketidak puasan pencapaian ekonomi. Dalam kondisi ini dimanfaatkan masa untuk melakukan aksi kerusuhan dengan bentuk pengerusakan dan penjarahan. Masa pilu yang dialami oleh etnik Tionghoa yaitu pada masa Orde Baru di Indonesia. Banyak peristiwa yang menelan banyak korban, mulai dari pembunuhan, penyekapan, penjarahan dan pengerusakan.

Etnik Tionghoa menjadi sasaran empuk amuk massa dalam periode perubahan besar baik pada sektor perekonomian maupun dunia politik di Indonesia. Tragedi kerusuhan di Jakarta dan beberapa daerah lain pada bulan Mei tahun 1998 sebagai akibat dari krisis ekonomi di Indonesia pada tahun 1997, mengakibatkan etnik tionghoa sebagai target utama jarahan dan amuk masa. Kerusuhan ini diawali oleh krisis ekonomi Asia dan dipicu oleh tragedi Trisakti, empat mahasiswa Universitas Trisakti ditembak dan terbunuh dalam demonstrasi 12 Mei 1998. Selain faktor pemicu tersebut, sebab utama dalam tragedi ini adalah sebagai bentuk kritik terhadap pemerintah Orde Baru. Pada 


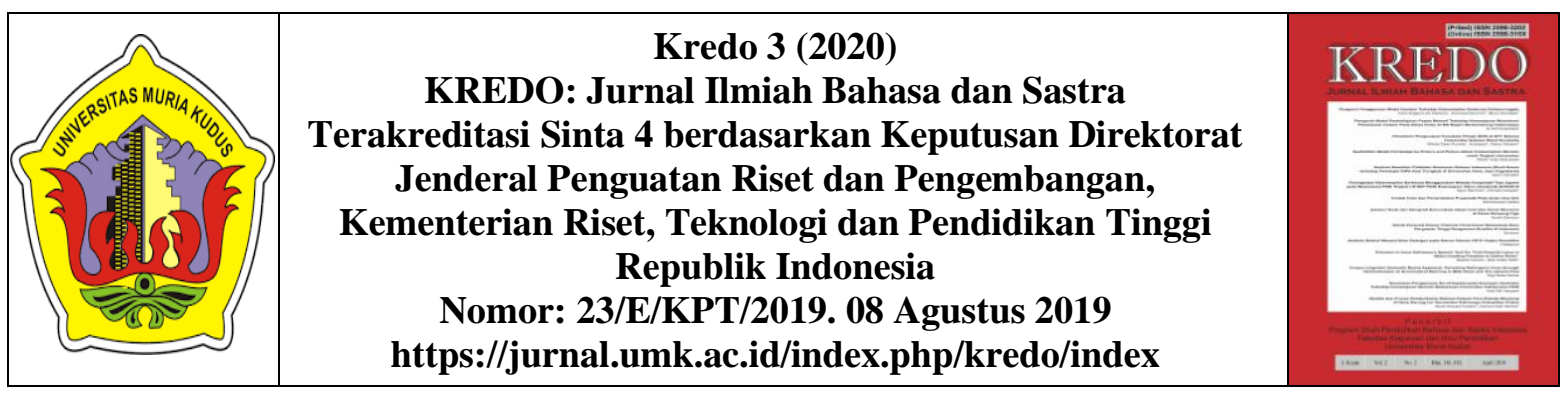

kerusuhan ini tidak sedikit toko dan perusahaan dihancur leburkan oleh amuk massa terumata milik etnik Tionghoa. Pusat kerusuhan terbesar terjadi di Jakarta, Medan dan Surakarta. Dalam kerusuhan ini ratusan wanita etnik Tionghoa yang diperkosa dan mengalami pelecehan seksual. Sebagian diperkosa ramai-ramai, dianiaya dengan sadis dan dibunuh. Terjadinnya kerusuhan tersebut banyak etnik Tionghoa meninggalkan Indonesia. Amuk massa ini membuat pemilik toko ketakutan dan mereka menulisi toko mereka dengan tulisan "Milik Pribumi" atau "Pro-reformasi" karena massa akan menyerang dan berfokus pada etnik Tionghoa.Tragedi ini mengakibatkan penurunan jabatan Presiden Soeharto dan di gantikan dengan B.J. Habibie.

Rekaman keadaan Indonesia pada masa Orde Baru banyak dituangkan dalam karya sastra, seperti novel, buku, cerita pendek, artikel, opini atau bahkan naskah drama. Karya sastra terbentuk karena pengalaman pribadi penulis yang digambarkan melalui tulisannya. Semua kejadijan terekam dalam karya sastra, yang dapat dinikmati oleh masyarakat. Salah satunya seperti novel Entrok karya Okky Madasari yang terbit pada tahun 2010 (Madasari, 2010). Novel Entrok di tulis oleh Okky Madasari. Okky Madasri adalah seorang pengarang Indonesia yang memenangkan karya sastra katulistiwa dengan karya sastranya. Okky lahir di Magetan pada tanggal 30 Oktober 1984. Dia pernah menempuh pendidikan di Universitas Indonesia dan Universitas Gadjah Mada. Karyakaryannya sudah banyak dikenal banyak orang, mulai darai novel pasung jiwa, Maryam, kerumunan terakhir, Mta Di Tanah Melus, The Out Cast, Mata dan Rahasia Pulau Gapi, Yang bertahan dan 74 | Jurnal Kredo Vol. 3 No. 2 April 2020 binasa perlahan, The last Crowd, Mata dan manusia laut, 86- English edition dan negeri para melus. Pengarang mengambil fakta sejarah pada masa Orde Baru di Indonesia era tahun 19501999 sebagai latar dalam novel tersebut. Dalam novel ini, penulis berusaha menggambarkan kejadian atau peristiwa politik yang terjadi di negara republik Indonesia dengan menghadirkan 1 tokoh yang berkesan dan membawa alur cerita dalam novel ini tidak monoton. Gambaran peristiwa tersebut digambarkan dengan rinci oleh pengarang, mulai dari adanya pembatasan etnis Tionghoa melakukan segala bentuk kegiatan, sampai pada peran uang dan kekuasaan menjadi sangat penting pada masa Orde Baru. Kesewenangan dan ketidakadilan digambarkan oleh penulis dengan berbagai peristiwa. Kisah dalam novel entrok sebenarnya sederhana, dua wanita yang hidup sangat sederhana penuh pejuangan melawan ketidakadilan dan kesewenang - wenangan. Akan tetapi yang identik dari novel ini adalah muncul beberapa tema yang besar tentang pluralisme, feminisme, politik, profesi, agama dan kepercayaan. Novel ini menjadi bahasan kompleks tentang kehidupan nyata dalam masyarakat pedesaan yang tertindas.

Pengarang mengambil fakta sejarah pada masa Orde Baru di Indonesia era tahun 1950-1999 sebagai latar dalam novel tersebut. Kisah dalam novel entrok sebenarnya sederhana, dua wanita yang hidup sangat sederhana penuh pejuangan melawan ketidakadilan dan kesewenang - wenangan. Akan tetapi yang identik dari novel ini adalah muncul beberapa tema yang besar tentang pluralisme, feminisme, politik, profesi, agama dan kepercayaan. Novel ini menjadi bahasan 


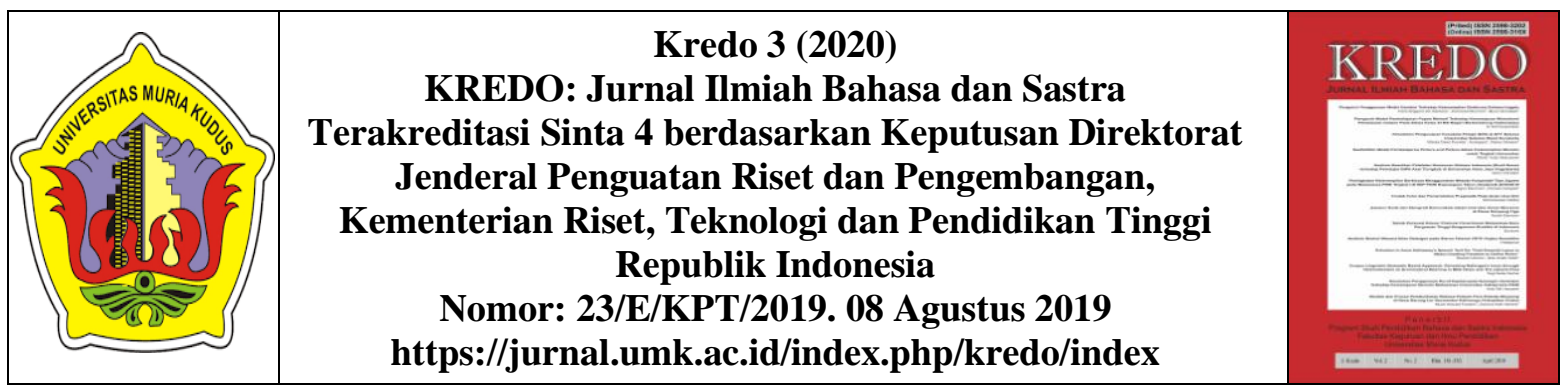

kompleks tentang kehidupan nyata dalam masyarakat pedesaan yang tertindas.

Dalam novel Entrok masa Orde Baru digambarkan oleh pengarang secara gamblang. Pengarang menggambarkan peranan kekuasaan dan uang pada masa Orde Baru menjadi hal yang sensitif bagi masyarakat Indonesia. Dalam masa Orde Baru kekuasaan seringkali dimanfatkan untuk menyelesaikan suatu masalah, sebab kekuasaan memiliki pengaruh yang sangat besar. Uang menjadi landasannya, dengan memberikan uang kepada masyarakat yang berpangkat atau yang berkuasa masalah bisa selesai tanpa rumit.

Penyalahgunaan kekuasaan yang dilakukan oleh penguasa dalam masa Orde Baru, menjadi pencekik leher bagi masyarakat. Kekuasaan dalam masa Orde Baru menjadi hal yang terpusat bagi sebagian para petinggi, kekuasaan tersebut dijalankan oleh beberapa orang yang berkuasa dari golongan atau kelompok tertentu. Adannya hal tersebut tentunnya pemerintah juga tidak memahami partisipasi publik dalam dunia politik secara kesepakatan (diskusi politik dan menyumbang suara dalam pemilu) maupun tidak mengikuti kesepakatan umum (demo dan unjuk rasa). Dalam novel Entrok juga digambarkan oleh pengarang tentang diskriminasi terhadap etnis Tionghoa yang diperlakukan secara tidak adil. Diskriminasi etnik Tionghoa yang dilakukan negara dalam novel Entrok dilakukan dengan cara memberikan kekerasan. Etnik Tionghoa dalam novel Entrok menjadi kaum yang di anggap oleh para penguasa sebagai sasaran kaum yang tertindas. Seperti peraturan tidak diperbolehkan menjalani ritual ibadahnya di Klenteng, jika tetap menjalankan maka ancaman dan hukuman diberlakukan. Melawanpun tetap ada hukuman yang harus diterima yaitu dipenjara dan dianggap PKI, musuh Negara. Hal ini dianggap sebagai etnik Tionghoa belum dianggap resmi sebagai agama resmi oleh pemerintah.

Penelitian terkait dengan kekuasaan pemerintah di era orde baru dan terekam dalam karya sastra telah muncul pada beberapa tulisan sebelumnya. Pertama, tulisan Fransiska Rini Wiharjo (Wiharjo, 2018) dengan judul penelitiannya Bentuk-bentuk Hegemoni dan Counter Hegemoni Dalam Novel Entrok Perspektif Antonio Gramsci yang berfokus pada konflik sosial dan aliensi dalam novel. Dalam penelitiannya penulis menggunakan pendekatan struktural dengan memfokuskan struktur karya sastra itu sendiri. Hasil dari tulisanya adalah tokoh utama yang juga menjadi tokoh antagonis adalah Marni, ibu dari Rahayu. Marni dianggap sebagai tokoh penggerak alur dalam cerita novel. Rahayu sebagai tokoh protagonis digambarkan sebagai tokoh kedua penggerak alur cerita. Bentuk hegemoni menurut penulis ini dibagi dalam dua wilayah, wilayah sipil dan wilayah politik. Penelitian kedua yang ditulis oleh Nurul Khotimah (Khotimah, 2014) dengan judul penelitiannya Diskriminasi Tokoh Perempuan Etnis Tionghoa Dalam Novel Dimsum Terakhir Karya Clara $\mathrm{Ng}$. Ada banyak fokus di dalam tulisannya salah satunya adalah respon tokoh perempuan etnis Tionghoa dalam melawan diskriminasi dalam novel Dimsum. Hasil dari penelitian tersebut respons tokoh perempuan etnis Tionghoa dalam melawan diskriminasi dibedakan menjadi dua yaitu respon 


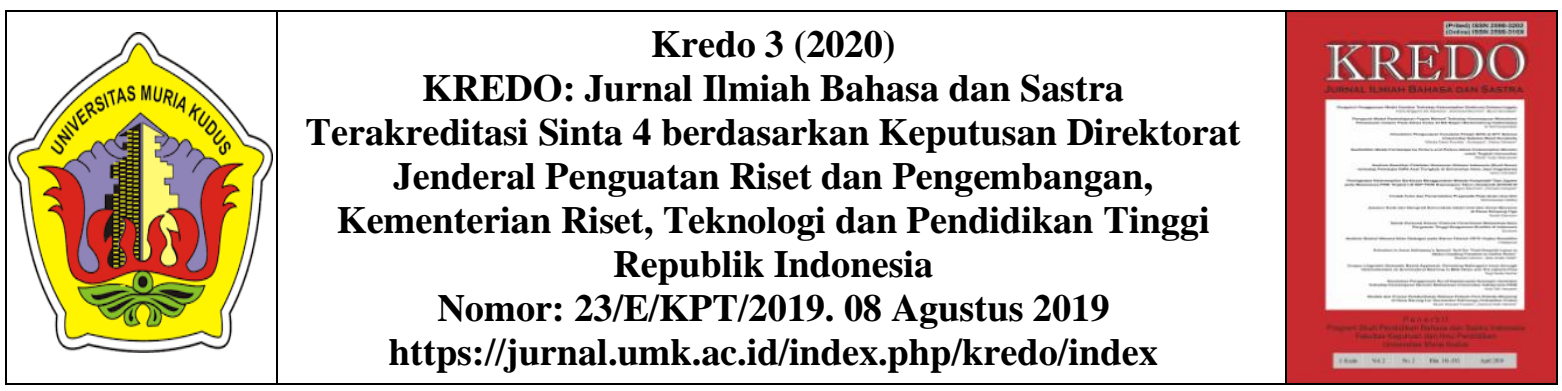

menolak dan menerima. Respon yang paling dominan adalah respon dalam menolak tindak diskriminasi. Bentuk dari sikap penolakan tersebut berupa tindakan verbal dan sikap mengritisi tindak diskriminasi.

Pentingnya penelitian ini ditulis untuk mendeskripsikan diskriminasi negara terhadap etnik Tinghoa dalam novel Entrok dan mendeskripsikan tujuan dominasi Negara terhadap etnik Tionghoa. Penelitian ini ditulis dengan harapan dapat menjadi sumbang pikir bagi dan bermanfaat bagi kehidupan pembaca. Serta menjadi refrensi dalam dunia kesastraaan. Fokus penelitian ini yaitu pertama dominasi negara kepada Tionghoa dengan kekerasan, kedua tujuan dominasi yang dilakukan negara terhadap etnik Tionghoa.

\section{KAJIAN TEORI}

\section{SELAIN \\ KEKUASAAN DENGAN CARA DOMINASI ATAU} KEKERASAN, juga muncul kekuasaan dalam bentuk moral dan intelktual. Kekuasaan ini diistilahkan dengan hegemoni. Hegemoni memiliki keterkaitan erat dengan konsep dan ideologi. Konsep hegemoni menurut Antonio Gramsci adalah suatu kelas dan anggotannya menjalankan kekuasaannya terhadap beberapa kelas yang dibawahnya dengan dua cara yaitu persuasi dan kekerasan (Hefni, 2012). Antonio Gramsci merupakan seorang teoritikus politik yang lahir di Ales, Italia dan meninggal pada 27 April 1937.

Kekerasan yang dilakukan oleh kelas atas terhadap kelas bawah dengan cara mendominasi kelas bawah. Kekerasan dilakukan melalui orangorang negara seperti polisi, hakim dan

76 | Jurnal Kredo

Vol. 3 No. 2 April 2020 tentara. Cara persuasi dilakukan dengan cara menghegemoni kelas bawah. Cara itu dilakukan dengan menanamkan gagasan dan ideologi yang bisa diterima tanpa harus ada penolakan. Gramsci melihat bahwa hegemoni adalah praktik dua arah dari dua hubungan yang subordinasi, yaitu kekuasaan negara kaum borjuis dan kelas buruh (Hutagalung, 2004). Dua wilayah menutut Gramsci dalam suatu negara dunia masyarakat sipil dan masyarakat politik. Bagi Gramsci hal terpenting dalam hegemoni adalah pentingnya kepemimpinan dan upaya-upaya untuk memenangkan kekuasaan pemerintah supaya ada kepuasan tersendiri.

Alasan munculnya hegemoni yaitu terpenuhinya akses dalam ruang material dan saluran menyuarakan gagasan dari kelas proletar adalah argumentasi alasan kelas yang idamkan Marx tidak tercapai (Wiharjo, 2018).

Sesuai dengan konsep hegemoni menurut pendapat Gramsci di atas, dalam novel Entrok tergambar jelas bahwa konsep hegemoni dijalankan oleh penguasa. Artinnya sistem politik di Indonesia pada masa Orde Baru menerapkan konsep hegemoni yang dilakukan oleh beberapa oknum elite. Dalam novel Entrok sanksi atau hukuman sering kali diberikan penguasa kepada masyarakat yang melanggar ketentuan, kebijakan, atau aturanatauran yang telah ditentukan. Dalam hal ini ketentuan, kebijakan, atau aturan tersebut merupakan bagian dari kekuasaan penguasa. Secara tidak langsung terdapat ancaman kepada masyarakat yang di sebabkan adanya ketentuan, kebijaran dan peraturan yang diberlakukan oleh penguasa. terlebih jika ada yang melakukan penolakan atau 


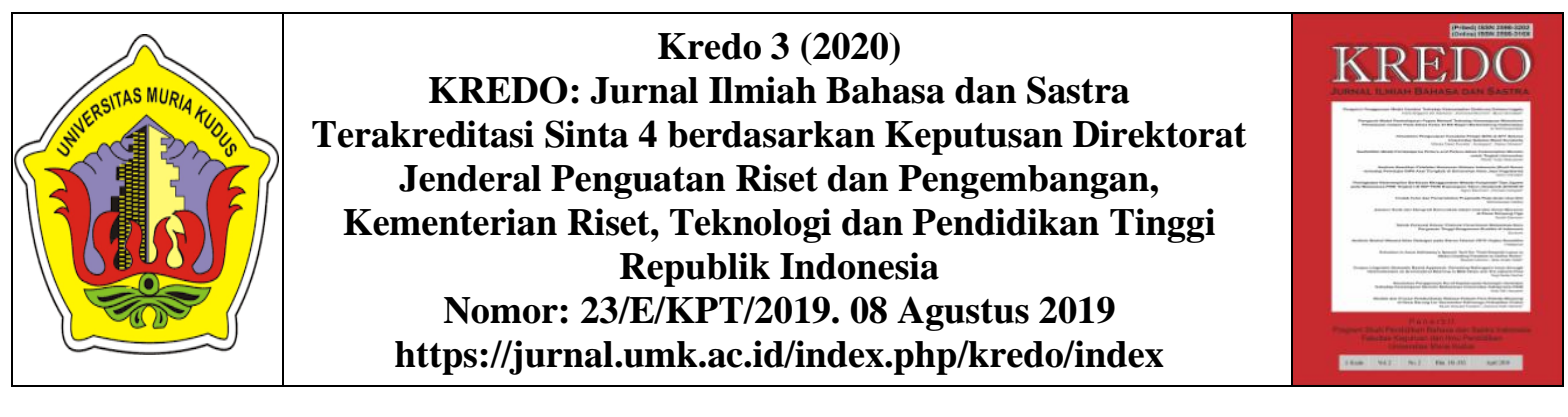

pemberontakan atas tindakan dari penguasa.

\section{METODE PENELITIAN}

Penelitian ini menggunanakan teori hegemoni perspektif Antonio Gramsci. Teori hegemoni merupakan acuan ilmu atau pendapat yang merujuk pada bentuk-bentuk pengaruh kepemimpinan, dominasi, kekerasan dan sebagainya dari sebuah Negara. Pendekatan yang digunakan dalam penelitian ini adalah pendekatan sosiologi sastra. Metode pengumpulan data dalam penelitian ini menggunakan studi pustaka, yaitu peneliti mengumpulkan dan membaca beberapa pustaka yang ada kaitannya dengan teori maupun objek yang dipakai, yaitu novel Entrok dan kajian teori hegemoni dengan pendekatan sosiologi sastra. Pendekatan sosiologi sastra merupakan pendekatan yang mengorientasikan manusia atau masyarakat kepada alam semesta sehingga pandangan yang dihasilkan sama persis dengan yang dihasilkan oleh penulis atau pengarang, serta pembaca dapat mengadapi kenyataan yang benarbenar nyata di lingkungan masyarakat.

Selain menggunakan studi pustaka peneliti menggunakan teknik simak dan catat. Kedua teknik ini bertujuan sebagai sarana pendukung berupa hal-hal penting yang terdapat dalam objek dan beberapa teks yang dijadikan sebagai bukti terjadinya peristiwa. Sumber data utama dalam penelitian ini adalah novel Entrok karya Okky Madasari yang diterbitkan PT Gramedia Pustaka Utama Jakarta, Tahun terbit 2017 (cetakan keempat) dengan tebal buku 282 halaman. Data dalam penelitian ini adalah frasa, kata dan kalimat yang berhubungan dengan fokus penelitian dalam penelitian ini.

\section{HASIL DAN PEMBAHASAN}

\section{Dominasi Negara Kepada Tionghoa dengan Kekerasan}

Dominasi yang dilakukan negara terhadap tionghoa dalam novel Entrok terjadi pada tokoh yang bernama Koh Cahyadi. Dalam novel Entrok digambarkan Koh Cahyadi adalah keturunan Tionghoa. Peran Koh Cahyadi sebagai kenalan dan rekan bisnis Marni. Koh Cahyadi memiliki usaha toko eletronik yang besar dan terbilang sukses di pasar besar. Setiap Marni ingin membeli barang elektronik atau kendaraan, selalu meminta bantuan kepada Koh Cahyadi untuk mencarikannya. Negara mendominasi etnik Tionghoa dalam novel Entrok yaitu dengan ancaman yang berkelanjutan. Dalam artian jika ancaman pertama telah diberikan dan etnik Tionghoa tetap saja melanggar maka tindakan Negara yaitu dengan memenjarakan orang tersebut. orang tersebut juga dituduh PKI karena dianggap melanggar dan membangkang peraturan negara. Hal ini bisa terjadi sebab di Indonesia tetulis dua peristiwa yang menjadi akar trauma oleh etnis Tionghoa, yaitu, peristiwa G30S PKI dan tahun 1965 kerusuhan Mei 1998 (F. Eriyanti, 2006) Dari dua peristiwa tersebut etnis Tionghoa menjadi sasaran utama masyarakat pribumi, sehingga sampai pada masa Orde Baru masyarakat Tionghoa masih mendapatkan perilaku yang tidak adil dan bersifat diskrimintif oleh pemerintah.

Kekerasan secara umum dikatakan Galtung (L. D. Eriyanti, 2018) sebagai sesuatu penghalang yang seharusnya dapat dihindari. Kekerasan ini dapat menyebabkan seseorang tidak bisa 


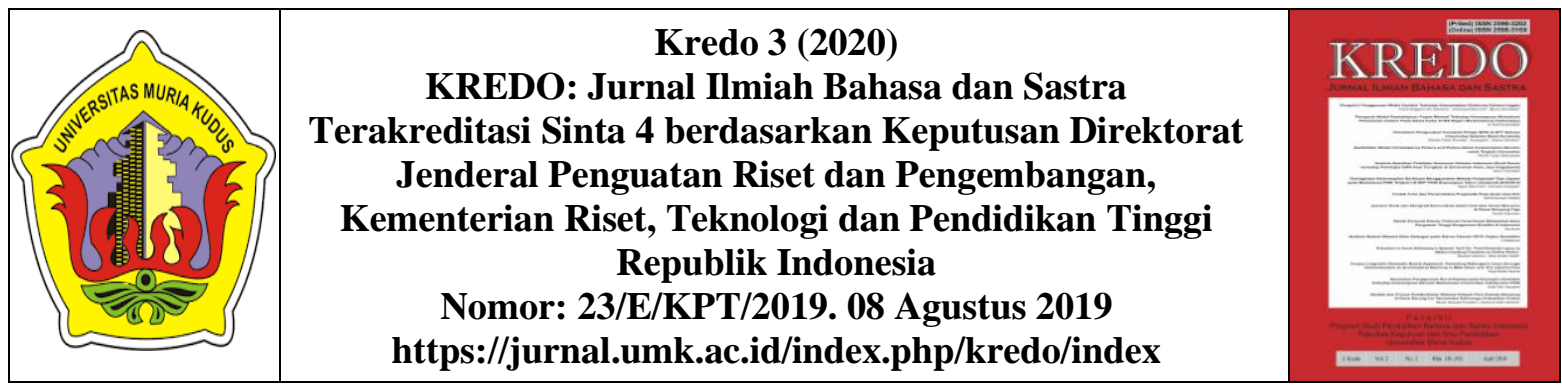

mengaktualisasikan dirinya sendiri dengan wajar.

Pada jaman Orde Baru banyak masyarakat Indonesia yang sangat tunduk terhadap peratuhan negara walau bukan keturunan orang Cina atau asli orang Cina. Hal ini dibuktikan pada data berikut.

(1)“ Aku tak tahu apa itu klenteng. Cik Ellin sepertinya ,engerti ketakutanku. Katanya kelenteng itu tempat orang-orang China menyembah leluhur. Mereka menyimpan abu nenek moyang dalam guci yang disimpannya di kelenteng, lalu berdoa di sana. Sejak goro-goro PKI, orang tidak boleh lagi ke kelenteng . kelenteng-kelenteng ditutup." (Madasari, 2010:108).

Pada data tersebut terdapat unsur ketakukatan terhadap peraturan politik yang berlaku. Seakan-akan masyarakat buta kebebasan, terkekang dan segala apapun dibatasi. Pada masa itu masyarakat tunduk terhadap segala apapun yang diperintahakan oleh oknum penguasa. Masyarakat tidak berdaya memberikan perlawanan yang kuat, selama masa yang dijalani berangsur lama. Data berikut sebagai bentuk tunduknya masyarakat terhadap penguasa politik.

(2)"Mohon maaf ndan, Istri saya ini memang tidak tahu mana yang benar dan mana yang salah. Maaf, ndan. Beribu maaf, ndan. Monggo datang lagi minggu depan, nanti kami siapkan jatah untuk uang keamanan." (Madasari, 2010:71)
Terbukti atas permintaan maaf dari orang tersebut kepada penguasa politik yang dipanggil dengan ndan. Mengemis dan memohon perminta maaf sebagai bentuk ketundukan masyarakat terhadap penguasa. Pada data tersebut menceritakan tentang tokoh utama yaitu Marni ketika dimintai uang keamanan, akan tetapi Marni memberikan perlawanan. Akhirnya timbul sedikit keributan antara Marni dan salah satu oknum penguasa yang dipanggil ndan. Ketika itu suami dari Marni, Tejo melerai dengan meminta maaf kepada oknum penguasa tersebut dan pura-pura menyalahkan istrinya, Marni. Uang keamanan pada masa Orde Baru diartikan sebagai uang sogokan yang harus dibayar masyarakat setiap bulan. Uang itu tidak untuk disumbangkan ke negara, akan tetapi uang itu menjadi hak milik pribadi penguasa. Semakin kedudukannya tinggi pembayaran uang keamanan setiap bulan semakin tinggi juga. tergantung dari status sosialnya.

Kesewang-wenangan juga dijadikan patokan untuk masyakat menghornati penguasa. Tindakan kekerasan yang berupa ancaman dan hukuman menjadi cambuk bagi masyarakat Indonesia asli dan masyarakat keturunan Cina. Bukti kesewenangan penguasa politik akan dibuktikan pada data berikut.

(3) "Hei, kang ! kowe kok kurang ajar begitu ! kami ini petugas. Ke sini bukan mau minta jatah. Kami hanya mau menjaga keamanan! Kata Sumadi dengan keras. Jarinya menunjuk-nunjuk muka Bapak." (Madasari, 2010:71). 


Kredo 3 (2020)
KREDO: Jurnal Ilmiah Bahasa dan Sastra
Terakreditasi Sinta 4 berdasarkan Keputusan Direktorat
Jenderal Penguatan Riset dan Pengembangan,
Kementerian Riset, Teknologi dan Pendidikan Tinggi
Republik Indonesia
Nomor: 23/E/KPT/2019. 08 Agustus 2019
https://jurnal.umk.ac.id/index.php/kredo/index

Pada data tersebut jelas terlihat jabatan menjadi kunci utama penguasa politik untuk bersikap sewenangwenang. Pada dasarnya ketika masa Orde Baru siapa yang mempunyai jabatan maka orang itu bisa melakuakn sewenang-wenangnya. Kekuasaan pemegang kunci utama dalam masa Orde Baru.

(4) "Ya,aku memang tidak tahu apaapa tentang masalah Koh Cayadi. Aku hanya orang desa yang bodoh yang kebetulan rumahnya ditumpangi buronan. Benar begitu kan?

“dia akan dipenjara?" tanyaku.

"pasti. Dia sudah melawan Negara. Mau jadi PKI apa!"

"salah dia apa to, ndan? Nggak ada bedanya sama kita yang bikin gobyong di punden"

"hus! Kalau tidak tahu apa-apa jangan sembarangan omong. Klenteng, tari naga, sampeyan tahu tidak itu simbol PKI. Makanya dilarang. Ini singkek sudah tau dilarang masih nekat" (Madasari, 2010: 182).

Saat Koh Cayadi ingin berbuat baik dan menjalankan kewajibannya, hal itu menjadi malapetaka bagi Koh Cayadi. Dia ketahuan membantu pendanaan untuk tari naga di Surabaya. Dia dipenjara dan dicap PKI. Perlakuan terhadap Koh Cayadi yang dilakukan oknum polisi dilakukan dengan cara kekerasan batin dan mental. Kekerasan ini termasuk dalam kekerasan secara langsung, menurut teori Galtung (L. D. Eriyanti, 2018:29) kekerasan langsung terbentuk dalam kekerasan klasik yang termasuk kekerasan fisik seperti pembunuhan, penyiksaan, pemerkosaan dan pemukulan atau aniaya. Kekerasan verbal seperti hujatan atau penghinaan.

(5) "Sekilas, dari pintu toko yang terbuka separuh, aku bisa melihat Koh Cayadi duduk di kursi yang biasa didudukinnya setiap hari. Disitu dia biasa menerima pembayaran dari orang-orang yang membeli dagangannya. Satu tentara duduk di kursi hadapanya, dua yang lain berdiri. Salah satu tentara yang berdiri berbicara sambil menunjuk-nunjuk muka Koh Cayadi. Muka Koh Cayadi pucat pasi, dia sama sekali tak bicara. Sekilas aku juga melihat tiga pegawai Koh Cayadi duduk di lantai, di belakang majikannya. Mereka ketakutan.Begitu melihat kami, Cik Ellen melambai, menyuruh kami masuk ke tokonya yang sumpek itu."itu lo, Yu Marni, kasihan si Koh Cayadi. Ada yang lapor ke tentara, kalau dia suka ke Klenteng." (Madasari, 2010:108).

Data diatas menunjukkan tentara mengancam dan mengintrograsi Koh Cayadi untuk mengakui kesalahan bahwa Koh Cayadi telah pergi ke Klenteng untuk melaksanakan ibadah. Terlihat bahwa wajah Koh Cayadi pucat pasi, dia mengalami kekerasan batin dan pikir. Sikap tentara terhadap Koh Cayadi dianggap tidak sewenang, akan tetapi peraturan pada Masa Orde Baru yang dengan sengaja mendiskriminasi etnik Tionghoa menjadi alasan utama. Kesewangan pemerintah terhadap pada masa Orde Baru juga menjadi ladang penguasa untuk memeras etnik Tionghoa 


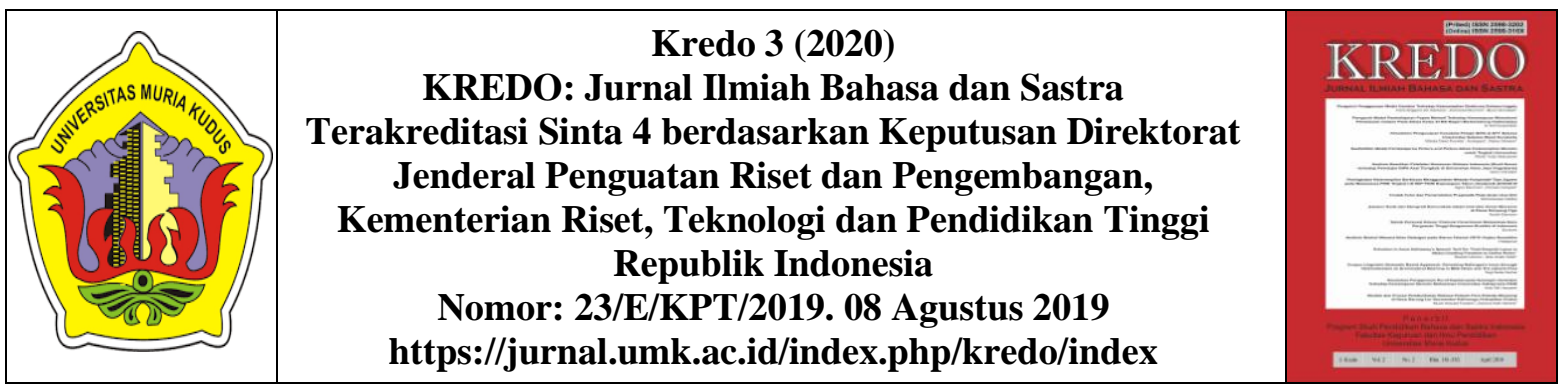

dalam skala besar. Artinya segala apapun urusan etnik Tionghoa jika melanggar aturan negara dimintai uang sogokan, tetapi tetap saja ditahan dan menjadi incaran.

(6) "terus tentara-tentara itu sekarang mau apa di toko si Koh, Cik?"

"tidak tahulah aku. Kami semua nggak ada yang berani ke sana.

Takut. Nanti malah kami kena masalah juga, dianggap sealiran sama Koh Cayadi." (Madasari, 2010:109).

Kekerasan yang diberikan oleh para oknum tentara mengakibatkan siapapun yang berhubungan dengan etnik Tionghoa pasti dianggap sealiran dengan etnik Tionghoa. Hal ini menjadi kekerasan batin yang dirasakan masyarakat terutama pribumi. Kekerasan dalam data di atas termasuk kedalam kekerasan secara langsung yang mengakibatkan seseorang tidak bisa mengaktualisasikan diri dengan baik.

(7) “Aku juga ke kelenteng. Koh Cayadi tertawa pelan. " Juga biar selamat, biar aku tercapai segala tujuan." Dia berkekeh lagi, pelan sekali, hingga menyerupai desahan. " tapi mesti sembunyisembunyi..ee...lha sekarang malah kucing-kucingan sama tentara." (Madasari, 2010:178).

Data di atas menunjukkan betapa dibatasinya kegiatan keagamaan etnis Tionghoa. Kegiatan keagamaan yang dilakukan Koh Cayadi dilakukannya secara diam-diam dan berusaha supaya tidak diketahui oleh siapapun. Bahkan $80 \mid$ Jurnal Kredo

Vol. 3 No. 2 April 2020 ada banyak etnik Tionghoa yang berpindah agama sesuai agama yang diresmikan di negara Republik Indonesia. Peraturan ini tertulis dalam peraturan negara bahwa di Indonesia agama Konghuju tidak diresmikan dan tidak dianggap. Koh Cayadi menjadi buronan dikarenakan dia pergi beribadah pergi ke kelenteng.

(8) "tak ada orang lain, selain keluargaku dan dia, yang tahu aku ke Klenteng. Hari ini tentara datang menanyai aku macam-macam. Siapa lagi yang bikin gara-gara kalau bukan dia?"

"mereka bilang, mereka tahu aku ke Klenteng. Katannya aku sudah melanggar aturan. Aku bilang tidak benar, aku tidak pernah ke Klenteng." Koh Cayadi berhenti.

"mereka bilang ada saksi yang melihat dan aku akan di penjara. Akhirnya aku mengaku. Aku bilang itu hanya demi ibuku yang sekarat."

"katannya ini peringatan. Mereka minta uang jaminan. Tapi kalau ketahuan sekali lagi aku mau ditangkap." (Madasari, 2010:111).

Uang jaminan menjadi kunci utama kebebasan dari jeratan hukuman atau ancaman yang dilakukan oleh penguasa. Akan tetapi uang jaminan itu sifatnya hanya sementara dan tidak ada gunannya, karena tetap saja pemenrintah akan memenjarakan siapa yang bersalah dalam melanggar peraturan negara. Data diatas menunjukkan Koh Cayadi bercerita kepada Marni tentang hal apa yang telah dilakukan oleh oknum 


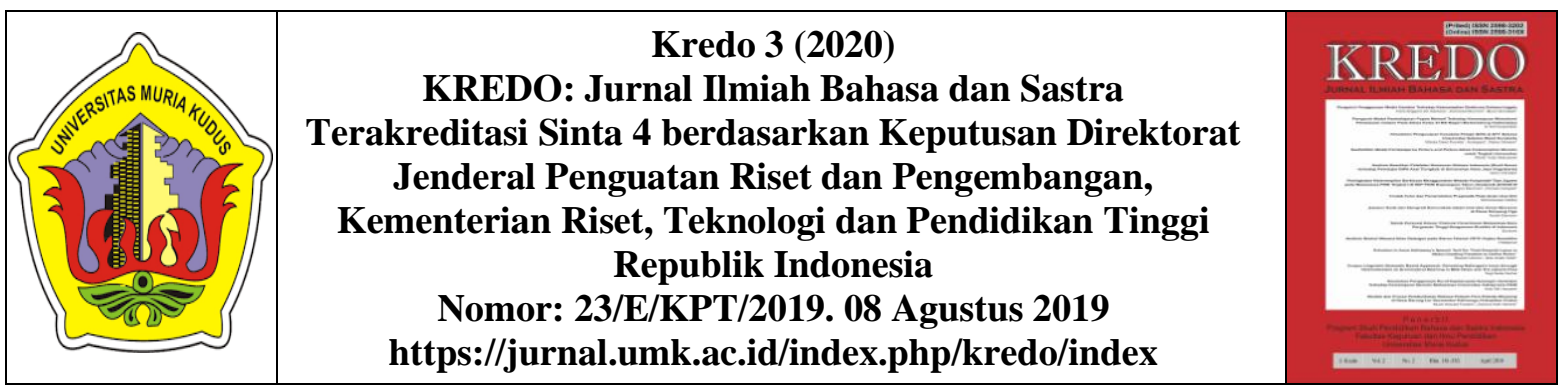

penguasa terhadapnya. Ketika itu Koh Cayadi pergi ke klenteng untuk mendoakan ibunya yang sedang sakit. Permintaan ibunya untuk Koh Cayadi pergi ke klenteng. Permintaan ini di anggap Koh Cayadi sebagai permintaan terakhir sebelum ibunya meninggal dunia. Kepergian Koh Cayadi ke klenteng ada yang mengetahui dan dilaporkan kepada oknum penguasa. Tidak lama dari kepergian Koh Cayadi, para oknum tersebut menghampiri dan mengintrogasi Koh Cahyadi ditempat. Beberapa pertannyaan diajukan dengan memberikan ancaman-ancaman hukuman, akan tetapi ujung dari introgasi tersebut adalah uang sogokan.

(9) "Dia malah diam ... aku semakin penasaran. Bagaimanapun aku juga takut kalau ada buronan menginap di rumah ini. Amitamit jabang bayi, jangan sampai aku jadi ikutan menjadi buron". (Madasari, 2010:170)

Pada data di atas tokoh Marni dimintai tolong untuk menyembunyikan kebedaraan Koh Cayadi yang menjadi buron. Marni merasa ketakutan apabila Marni nantinya juga dituduh sebagai pelindung orang yang salah atau menyembunyikan buronan dalam rumahnya. Hal tersebut termasuk bukti bahwa kesalahan yang diperbuat Koh Cayadi dimata penguasa sangat besar. Padahal yang dilakukan Koh Cayadi jika diperhatikan hanya sebuah tindakan yang memang berhak dia lakukan, yaitu berdoa di tempat yang ia yakini. Marni sempat terlintas dalam ;pikiranya ragu untuk menerima Koh Cayadi menginap di rumah Marni sebagai tempat persembunyiannya. Akan tetapi Marni tidak tega, Marni ingat kebaikan dari
Koh Cayadi yang sudah membantunya untuk mencarikan TV dan mobil yang dibeli Marni. Kebaikan Koh Cayadi juga tidak hanya itu, Koh Cayadi pernah mengajak Marni pergi ke Gunung Kawi untuk melakuakan doa kepada leluhur yang ada di sana, sampai Marni mendaptkan salah satu bagian dari pohon Dawandaru yang dianggap sebagai sumber rezeqy.

(10) "Terus sampeyan mau sembunyi disini?" "Ya kalau diijinkan, Yu sementara saja. Mudah mudahan mereka tidak mencariku. Hanya disini yang aman yu." (Madasari, 2010:172)

Data di atas menunjukkan ketakutan Koh Cayadi terhadap para penguasa, sampai memohon kepada Marni pemilik rumah untuk diijinkan supaya dia dapat bersembunyi di rumah Marni. Sisi lain Marni sebagai teman Koh Cayadi ragu untuk membantu Koh Cayadi untuk menginap di rumahnya. Keadaan semakin membuat Marni sedikit panik, takaut jika Marni juga terseret dalam penjara. Sampai akhirnya Marni mengijinkan Koh Cayadi untuk menginap di rumahnya sebagai tempat persembunyiannya.

Pada data di atas terdapat selanjutnya terdapat lanjutan bahwa tidak hanya Koh Cayadi saja yang menjadi buronan. Istri dan anaknya juga menjadi buronan, akan tetapi istri dan anak dari Koh Cayadi melarikan diri pergi ke Malang, kerumah saudara Koh Cayadi untuk menyelamatkan diri dari tangkapan penguasa.

(11) "Sekarang tidak bisa yu. Kalau aku tidak lari pasti aku di 


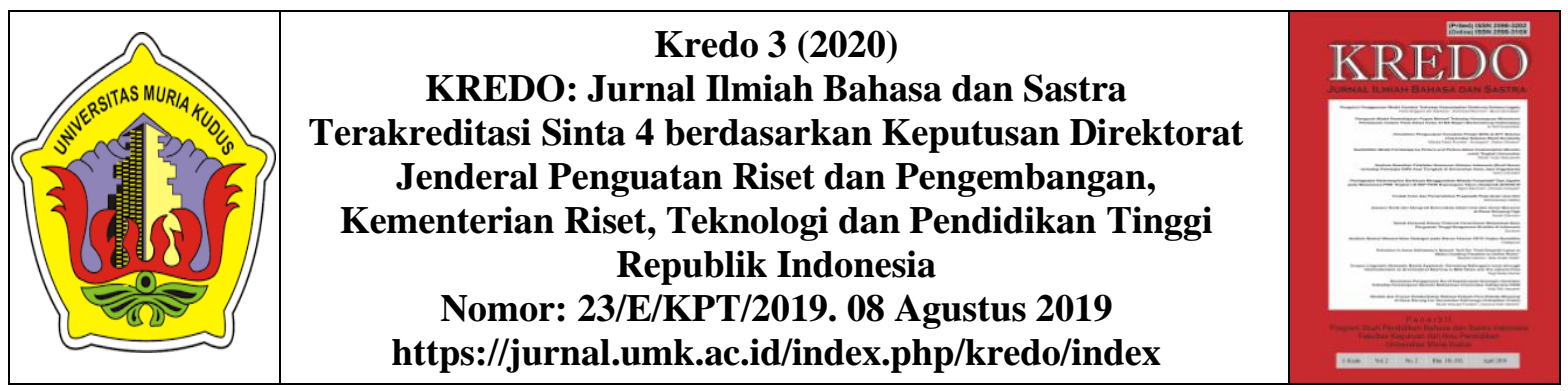

penjara". Koh Cayadi menggeser kursi mendekatiku. Suarannya dipelankan. Selama ini aku kan menyumbang duit buat latihan tari naga di kelenteng. Surabaya sana. Semuanya sembunyi-sembunyi. Tidak ada yang tahu, selain orang tua ku. Istriku sendiri saja tidak tahu. Kemarin tahun baru kami, mereka bilang-bilang main di lapangan sebelah kelenteng. Padahal itu tidak boleh. Semua orang yang main ditangkap."

(Madasari, 2010:171)

Data diatas menunjukkan Koh Cayadi bercerita kepada Marni tentang peraturan negara yang tidak memperbolehkan segala aktivitas yang berhubungan dengan kelenteng dilarang dan akan mendapat hukuman. Koh Cayadi sebagai juragan yang mempunyai kekayaan yang lumayan rutin menyalurkan dana untuk kegiatan tari naga di kelenteng. Hal itu dilakukan oleh Koh Cayadi secara sembunyi-sembunyi, akan tetapi kegiatan Koh Cayadi diketahui oleh tentara, sampai pada akhirnya Koh Cayadi menjadi buronan yang akan dipenjakan.

(12) "Hus kalau tidak tahu apa-apa jangan sembarangan omong. Kelenteng, tari naga, sampeyan tahu tidak, itu simbol PKI. Makannya dilarang. Itu, singkek sudah tau dilarang masih nekat."(Madasari, 2010:182)

Data di atas menunjukkan sikap tentara yang menghakimi salah satu etnis Tionghoa yang menjadi tokoh dalam novel entrok, yaitu Koh Cayadi.

82 | Jurnal Kredo

Vol. 3 No. 2 April 2020
Segala apapun yang berhubungan dengan etnik Tionghoa dianggap PKI. Mulai dari simbol di kelenteng, warna merah dan segala bentuk kegiatannya di cap sebagai PKI. Tidak hanya sampai disitu, masyarakat Indonesia yang melanggar aturan negara atau memberikan perlawanan terhadap penguasa maka akan dianggap PKI dan dipenjarakan. Begitu juga dengan masalah pembayaran uang keamanan yang dibayarkan setiap bulan. Jika uang tersebut tidak dibayarkan secara rutin, maka penguasa akan memberikan hukuman yang berupa di cap sebagai PKI dan dipenjarakan. Kata singkek pada data tersebut adalah sebutan bagi orang Cina yang berdomilisiri di Indonesia, atau biasa gunakan untuk melabelli orang Tiongkok yang mempunyai sifat pelit dan kikir.

(13) "Melalui kaca nako, aku bisa melihat mereka, orang-orang berpakaian hijau. Ini hari kamis, biasannya mereka datang senin atau selasa. Mereka bukan orang-orang yang biasannya datang ke sini. Pintu digedor dengan kasar, mengirimkan pesan ancaman dan ketakutan. Begitu pintu kubuka, mereka menodongkan senapan. Mereka masuk rumah, tanpa permisi padaku. Menggeledah semua kamar, membuka semua lemari. Entah kali ini Koh Cayadi bisa lolos atau tidak. Dalam penantian, aku merasa waktu berhenti. Pandanganku tak beralih dari arah pawon, sembari mengucapkan permintaan pada penguasa alam. Gusti, berilah kami semua keselamatan. Tapi keberuntungan Koh Cayadi 


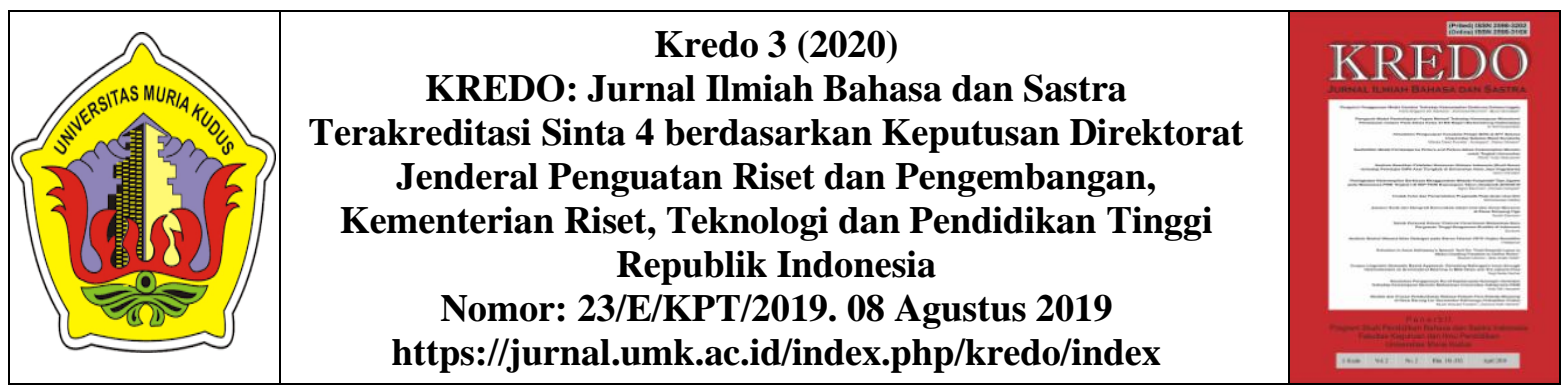

kemarin tak terulang algi hari ini. Dari lorong pawon dia berjalan dengan ujung senapan yang menempel di punggungnya. Dua tentara dibelakangnya." (Madasari, 2010:180)

Data di atas menunjukkan bahwa tentara benar-benar akan mencari buronan yang melanggar aturan negara sampai ketemu dan akan dipenjarakan. Keberuntungan Koh Cayadi pada pencarian keduanya oleh tentara tidak berpihak lagi. Dia tertangkap dan digiring ke kantor polisi. Marni terlihat khawatir dan takut jika akan ditangkap juga karena telah menyembunyikan buronan dalam rumahnya. Hal itu terbukti dengan tindakan Marni yang berdoa kepada alam semesta meminta untuk diberi keselamatan.

(14) " ini siapa bu..?" tanya tentara yang dari tadi berdiri di sampingku. Dia komandan tentara-tentara ini. "teman saya, Pak. Punya toko di pasar gede Madiun.”(Madasari, 2010:181)

Pada data di atas Marni berusaha jujur dengan pertanyaan yang diajukan tentara, supaya masalah yang akan dihadapi tidak semakin rumit. Tentara itu sengaja menannyakan kepada Marni tepat di depan Koh Cayadi supaya Koh Cayadi merasa dipermalukan. Pada akhirnya tetetap saja Marni juga dibawa ke kantor polisi untuk dimintai keterangan. Ketika dimintai keterangan ada salah satu komandan yang datang menghampiri Marni dengan menannyakan apakah Marni masih ingat denganya. Tentu aja Marni ingat siapa dia, dia adalah orang yang rutin setiap hari senin atau selasa datang ke rumah Marni untuk mengambil uang keamanan. Marni sudah berprasangka, pasti akan dimintai uang sogokan untuk membebaskan dia dari jeratan penjara. Ternyata tebakan Marni benar, Marni dimintai nuang dengan alasan untuk tidak dipenjarakan.

\section{SIMPULAN}

Berbagai kebijakan asimilasi yang menjurus kepada diskriminasi etnik Tionghoa karena bersifat memaksa, menjadikan segala apapun yang dilakukan oleh etnik Tionghoa di persulit. Baik dalam bidang ekonomi, politik, dan budaya. Hal itu menimbulkan hegemoni Negara terhadap etnik Tionghoa baik dalam bentuk kekerasan maupun tidak. Tujuan dari dominasi yang dilakukan dengan menggunakan hegemoni yaitu untuk menegak kan peraturan yang berlaku pada masa orde baru. Cara yang dilakukan pemerintah dalam menjalankan tugas negarannya tidak tepat karena para petugas mengambil kesempatan untuk menguntungkan dirinya dengan membuat peraturan harus membayar uang keamanan. Apabila tidak menuruti hal tersebut maka akan dianggap PKI.

Dalam novel entrok, kekerasan yang di lakukan oleh para penguasa dilakuakan dengan kekerasan secara langsung, dalam bentuk kekerasan fisik, kekerasan batin dan kekerasan pikiran. Juga ditemukan kekeras intelektual yang terbukti dengan peraturan pemerintah yang menutup sekolah-sekolah bahasa mandarin. Dalam novel entrok juga mendominasi peran uang dan kekuasaan pada masa Orde Baru menjadi mahkota penguasa dalam menindas rakyat pribumi dalam kesederhanaan dan pada etnik 


Kredo 3 (2020)
KREDO: Jurnal Ilmiah Bahasa dan Sastra
Terakreditasi Sinta 4 berdasarkan Keputusan Direktorat
Jenderal Penguatan Riset dan Pengembangan,
Kementerian Riset, Teknologi dan Pendidikan Tinggi
Republik Indonesia
Nomor: 23/E/KPT/2019. 08 Agustus 2019
https://jurnal.umk.ac.id/index.php/kredo/index

Bisa dikatakan akar kebencian terhadap etnis Tionghoa sebenarnya merupakan kontruksi sosial yang dibuat oleh penguasa, baik Belanda maupun Jawa. Secara tidak langsung dalam hal ini etnis Tionghoa menjadi korban kambing hitam.

\section{DAFTAR PUSTAKA}

Adam, A. W. 2019. Tionghoa dan KeIndonesia-an: Komunitas Tionghoa di Semarang dan Medan. Jakarta: Yayasan Pustaka Obor Indonesia. 3

Dawis, A. 2013. Orang Indonesia Tionghoa Mencari Identitas. Gramedia Pustaka Utama.

Eriyanti, F. 2006. Dinamika posisi identitas etnis Tionghoa dalam tinjauan teori identitas sosial. Jurnal Demokrasi, 5(1).

Eriyanti, L. D. 2018. Pemikiran Johan Galtung tentang Kekerasan dalam Perspektif Feminisme. Jurnal Hubungan Internasional, 6(1), 2737.

Fittrya, L. 2013. Tionghoa Dalam Diskriminasi Orde Baru Tahun 1967-2000. Avatara, 1(2).

Hefni, M. 2012. Runtuhnya Hegemoni Negara dalam Menentukan Kurikulum Pesantren. KARSA: Journal of Social and Islamic Culture, 19(1), 62-72.

Hutagalung, D. 2004. Hegemoni, Kekuasaan, dan Ideologi. Jurnal Pemikiran Sosial, Politik Dan Hak Asasi Manusia.

Khaliesh, H. 2014. Arsitektur Tradisional Tionghoa: Tinjauan Terhadap Identitas, Karakter Budaya dan Eksistensinya. Langkau Betang: Jurnal

84 | Jurnal Kredo Vol. 3 No. 2 April 2020
Arsitektur.

https://doi.org/10.26418/lantang.v 1i1.18811

Khotimah, N. (2014). Program studi pendidikan bahasa dan sastra indonesia fakultas bahasa dan seni universitas negeri yogyakarta juni 2015 (Universitas Negeri Yogyakarta). Retrieved from https://eprints.uny.ac.id/17943/1/N urul Khotimah 09210144035.pdf

Madasari, O. 2010. Entrok: sebuah novel. PT Gramedia Pustaka Utama.

Nurcahyo, D. A. 2016. Kebijakan Orde Baru Terhadap Etnis Tionghoa. Universitas Sanata Dharma Yogyakarta.

Romli, K. 2015. Akulturasi dan Asimilasi dalam Konteks Interaksi Antar Etnik. Ijtimaiyya: Jurnal Pengembangan Masyarakat Islam, 8(1), 1-13.

Suryadinata, L. 2014. Kebijakan Negara Indonesia terhadap Etnik Tionghoa: Dari Asimilasi ke Multikulturalisme? Antropologi Indonesia.

Wiharjo, F. R. 2018. Bentuk-Bentuk Hegemoni dan Counter-Hegemoni dalam Novel Entrok Karya Okky Madasari (Universitas Sanata Dharma). Retrieved from https://repository.usd.ac.id/30919/ 2/144114021_full.pdf 